\title{
Comparative Studies between Urbanization and Dam Settlement Processes
}

\author{
Cristiano Poleto ${ }^{1}$, Felippe Fernandes ${ }^{2}$
}

\begin{abstract}
The city of Viamão is located in the metropolitan region of Porto Alegre, in the Rio Grande Sul State, southern Brazil. The Mãe d'Água dam was built in 1962 and, due to the lack of urban planning during the last forty years, received large discharges of sediments and contaminants (organic and/or inorganic). This study aimed to use the geochronology technique using the lead element $210(210 \mathrm{~Pb})$ through the cores of sediments sampled from the Mãe D'água dam and to establish the chronology of the sedimentary layers over the last four decades, in addition to the characterization of the sedimentation processes in the Mãe D'Água reservoir and to size the sediment volumes silted in the reservoir in the current scenario, year 2014 (year of sampling) and thus, to present the total sediment concentrations during the 40-year silting. The sediment column, bathymetry, bibliographical references and GIS resources were used to infer the process of urbanization and sedimentation process of the dam, and representative samples were collected in June 2014, using sediment cores distributed in the dam area. The sediment cores were extracted through the "Piston core" sampler. With the results obtained, graphs and tables were generated to create the mathematical models and later the sedimentation maps, establishing correlations with the sedimentation geochronology studies during the last four decades (layers of sedimentation generated in each of these periods). There were periods with high sedimentation rates, mainly during the acceleration of the process of urbanization of the basin resulting in a total sediment volume of $44 \%$ of the useful volume of the project, which drastically reduces the capacity of the Mãe d'Água dam.
\end{abstract}

Keywords: Urban dams, Sediments, Sedimentation of dams.

\section{Introduction}

Urban growth on the banks of water bodies has led to the degradation of water quality, leading to significant losses for aquatic ecosystems and public health. In addition to this rapid and disorderly growth, inadequate soil use is currently one of the main causes of degradation of natural resources, causing damages not only due to hydrological changes, but also as a result of the load of pollutants carried along the sediments, reaching their final destination which is the sedimentation in lentic water bodies.

According to Lima (2000), sediments accumulated in estuaries and lakes contain a valuable historical record on changes caused by anthropic processes. Sediment geochronology acts as an instrument to the determination of the recent history of silting and pollution and has been applied more frequently because its methods of analysis have been improved, leading to a high degree of significance in studies of environmental impacts. The presence of radioactivity in the sediments is due both to the decay of the $\mid{ }^{1} \mathrm{Ph} . \mathrm{D}$. Professor of the Department of Hydraulic Research of the Federal University of Rio Grande do Sul - Bento Gonçalves Avenue, 9500. Porto Alegre- Brazil

| ${ }^{2}$ Doctoral student of the Department of Environmental Engineering Sciences of the School of Engineering of São Carlos of the University of São Paulo, km 13 of Domingos Innocentini Highway, City of Itirapina Brazil. 
radioactive elements originally present in the sediments, as well as owing to those removed from the atmosphere by precipitation with rain and deposited through sedimentation processes. Therefore, it can be considered as the ideal radionuclide for dating sediments of recent age (MOZETO, 2006). Recently, a large majority of the studies that aim to evaluate the sedimentation or the sedimentation volume have chosen to use the $210 \mathrm{~Pb}$ method, mainly in lentic environments such as lakes and dams (ALMEIDA, 2003; BONOT'TO e LIMA, 2006; LIMA, 2000).

Measuring the impacts of urbanization on the evolutionary process of enrichment by contaminants among the granulometric ranges of the sampled lake sediments is of high importance in the field of hydrosedimentology. The technique has turned out to be advantageous justified by the relatively low cost to simulate real systems. Assuming that the pollution generated in watersheds in urban areas are added to the deposited sediments, among the methods available for the study of sediment transport, the idea was to elaborate an evolutionary map of sediment volume in the last decades through the use of geochronology by $210 \mathrm{~Pb}$ and software for measurement which allowed to visualize the sediment deposition period, identifying its influence under the process of urbanization evolution in the basin that makes up the Mãe d'Água dam.

\section{Materials and Methods}

\subsection{Study Area}

The sampled site is located in the Rio Grande do Sul State, metropolitan region of Porto Alegre, more precisely in the municipality of Viamão. The Mãe d’Água dam is a tributary of the Arroio Dilúvio, an important water course that extends to the municipality of Porto Alegre, cutting it in the East-West direction.

The Mãe d`Água dam is the mouth of four streams, corresponding to an area of 353 ha and it is located in the Campus Valley of the Federal University of Rio Grande do Sul. Figure 1 represents the study area, characterizing the location and the size of the dam.

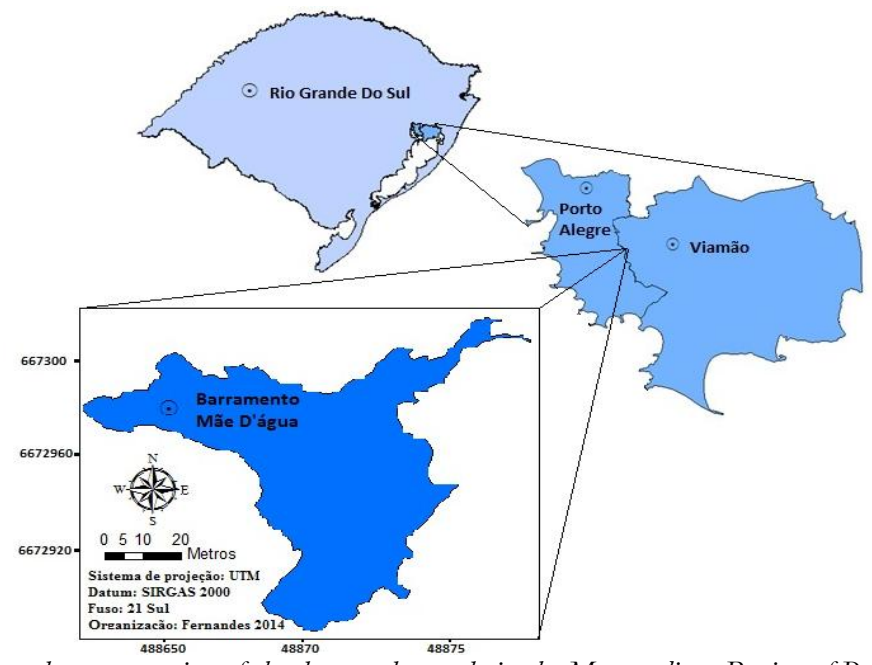

Figure 1: Location and representation of the dam under study in the Metropolitan Region of Porto Alegre, RS. 


\subsection{Sampling}

The collection of the cores and the bathymetric sampling was performed on 06/09/2014. The points for collecting the samples were designed to obtain a better spatial distribution in the lake. Eight points were sampled in the lake and their geographic coordinates, height of the water table and the length of the sedimentary profile collected were collected (Table 1).

The technique used was the Core Sampling, being a set of detachable parts, consisting of the introduction of a cylindrical rigid PVC tube of $75 \mathrm{~mm}$ diameter in the bottom sediment, according to Fernandes and Poleto (2017a).

Table 1: Information on the core samples

\begin{tabular}{|c|c|c|c|c|}
\hline \multirow{2}{*}{$\begin{array}{c}\text { Sample } \\
\text { (Core samples) }\end{array}$} & \multicolumn{2}{|c|}{$\begin{array}{l}\text { Coordinates UTM (m) } \\
\text { ( WGS-84 Ellipsoid) }\end{array}$} & \multirow{2}{*}{$\begin{array}{l}\text { Water } \\
\text { table (m) }\end{array}$} & \multirow{2}{*}{$\begin{array}{l}\text { Core samples } \\
\text { length }(\mathrm{m})\end{array}$} \\
\hline & X & $\mathrm{Y}$ & & \\
\hline $\mathrm{T}-1$ & 488716,3334 & 6672912,682 & 1,46 & 0,62 \\
\hline T- 6 & 488681,4642 & 6672977,900 & 0,44 & 1,62 \\
\hline T- 8 & 488633,5455 & 6672976,312 & 1,00 & 1,06 \\
\hline
\end{tabular}

\section{$2.3{ }^{210} \mathrm{~Pb}$ Geochronology}

The total digestion EPA method 3052 was selected to open and digest the sediments, according to the usual methodology and procedures recommended by Mora (2015), considered suitable for applications that require total digestion of samples. This protocol is from the Environmental Protection Agency (USEPA).

The methodology used is based on the sequential radiochemical separation of 226Ra and $228 \mathrm{Ra}$ by co-precipitation with barium and radio sulfate and $210 \mathrm{~Pb}$ by co-precipitation with lead chromate, followed by total alpha and beta counts. The technique selected is suitable for environmental measurements in which the concentrations of $210 \mathrm{~Pb}$ activity are very low and when there are very small aliquots of the mass of the pellet available for testing. Finally, the determination of sediment age was reached through the C.R.S. method. (Constant Rate of Supply).

The mathematical formulation uses an integration of the values of the activities and it should be taken into account the depth of the sample of the extracted sediment and the depth where the activity becomes negligible (ALLEN et al., 1993; MCDONALD e URBAN 2007; TURNER e DELORME, 1996). Thus, it is determined by Equation 1.

$B_{z}=B^{\infty} \cdot e^{-\lambda}$

Equation 1

Where $\mathrm{Bz}$ is the integrated activity of $210 \mathrm{~Pb}$ "not produced" from the base of the sedimentary column to the depth $\mathrm{z}$; $\mathrm{B} \infty$ represents the integrated activity across the sediment column and $\lambda$ the $210 \mathrm{~Pb}$ radioactive decay constant $(0,0311$ year- 1$)$. The sediment age at depth $\mathrm{z}$ is then given by Equation 2 .

$\mathrm{t}=(1 / \lambda) \cdot \ln \left[\mathrm{B}^{\infty} / \mathrm{B}_{\mathrm{z}}\right]$

Equation 2

Where $\mathrm{t}$ is the sample age of the sediment; $\lambda$ the $210 \mathrm{~Pb}$ radioactive decay constant (0.0311 year- 1$) ; \mathrm{B} \infty$ represents the integrated activity across the sediment column and $\mathrm{Bz}$ is the integrated activity of $210 \mathrm{~Pb}$ "not produced" from the base of the sedimentary column to the depth $z$.

The dating technique with $210 \mathrm{~Pb}$ has been diffused among works regarding the 
management of water resources. Satisfactory results of great relevance in the establishment of an environmental history were obtained, referring to the geochronology of sediments of up to about 150 years, gaining greater relevance even when applied in regions of intense anthropic activities, since sediments of estuaries and lakes keep a valuable record with historical information on environmental changes as a result of industrial activity (ALEXANDER et al., 1993). Recently, the large majority of the studies that aim to evaluate the sedimentation or sedimentation volume have chosen to use the $210 \mathrm{~Pb}$ method, mainly in lentic environments such as lakes and dams (ALMEIDA, 2003; BONOTTO and LIMA, 2006; LIMA, 2000; FERNANDES and POLETO 2017b).

\subsection{Sedimentation}

For the analysis of the volume calculations, the initial conditions in 1962 of the dam, its date of construction and, later on, the dimensioning of the volume of silted sediments until the year 2014 were analyzed. Then, it was carried out the planning and the field exits in 2014, 2015, 2016 and 2017, with 4 samples being taken to achieve the top-bathymetric survey of the dam and to obtain the data for those analyzes.

The application of the methodology for computational modeling in the Mãe D'Água dam, inferring about the useful volume of the project in 1962, useful volume in 2014 and the silting volume, was developed with the help of the following software: AutoCAD 2018, AutoCAD Civil 3D 2018 and Google Earth. Those are specialized in the field of geoprocessing and guidelines for the calculations that use as base the data referring to the survey and the processing of the field data which were the bathymetric sampling of the sediment profiles collected and the survey of bibliographical materials gathered in technical research within the library of Geosciences and the Institute of Hydraulic Research both located at the Federal University of Rio Grande do Sul.

Through the software, the area for each of the isobaths was projected and calculated, from the minimum quota to the related quota as the normal level that makes up the reservoir. It was dimensioned the useful volume in 1962 and 2014 and also the volume silted inside the reservoir through the methodology established by its developers, using the conic approximation method. The quota, area and volume data were inserted in spreadsheets and were displayed in the results item below.

The calculation method for the conic approximation method from the AutoCAD Civil 3D 2018 software calculates the volume between two cross sections across the areas, which are added with the square root of their product and multiplied by the third of the distance between the areas to determine the volume, as expressed by Equation 4. Regarding the total volume, it corresponds to the sum of all partial volumes. The conic approximation method is expressed by the following Equation 3:

$$
V=\left(\frac{h}{3}\right) \times\left(A_{1}+A_{2}+\sqrt{A_{1} \times A_{2}}\right) \quad \text { Equation 3 }
$$

Where $\mathrm{V}$ is volume between two consecutive isobaths, $\mathrm{h}$ is the difference of dimension between the contours, A1 being the area comprised by the isobath and A2 the area comprised by the isobath. 


\section{Results}

\subsection{Geochronology with ${ }^{210} \mathrm{~Pb}$}

The T1, T6 and T8 samples from the sediments of the Mãe d'Água dam showed good linearity, constituting an ideal environment to the chronological study. Figure 2 shows the year of the $210 \mathrm{~Pb}$ chronology of the sedimentary layers deposited over the decades, as a function of depth. The geochronology analyzes presented a good linearity, inferring in good results for the study, with $\mathrm{R}^{2}$ for T1 equal to 0.92 and for T6 equal to 0.96 and $\mathrm{T} 8$ corresponding to 0.89 .

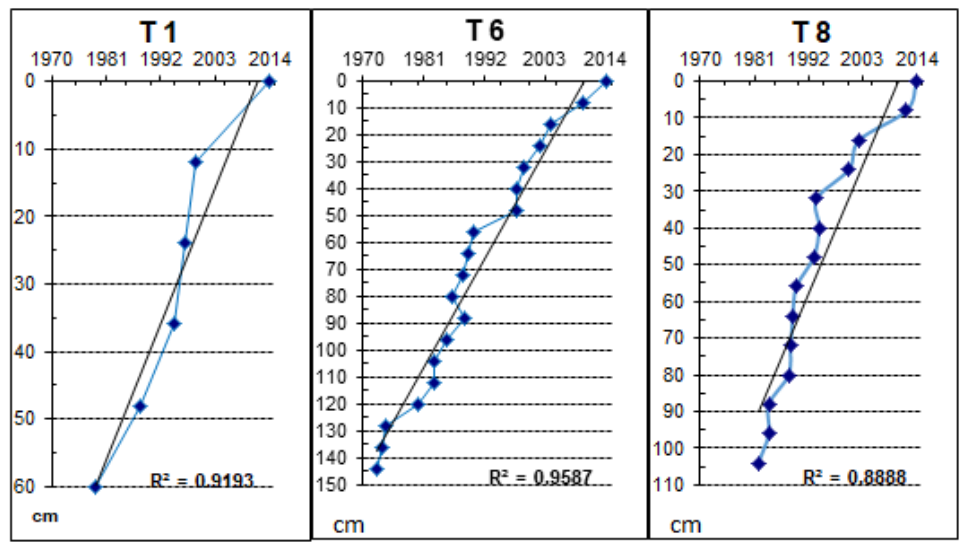

Figure 2: Geochronology of the sediment profiles sampled in the Mãe d'Agua dam.

The profile or sediment core sampled in the Mãe d'Água dam denominated by T1 corresponds to a period of geochronological accumulation of sediments at 35 years, with the most recent layer dated in 2014 and the deepest one reaching the year of 1972. Its mean sedimentation was $1.77 \mathrm{~cm}$.year- 1 . The sediment core named T6 presented age of 42 years and average sedimentation rate of $1.86 \mathrm{~cm}$.year- 1 . The sedimentation rate presented slight variations in the analyzed sedimentary records, which suggests that this area of the reservoir received volumes of sediments produced by the hydrographic basin in a constant way during the identified sedimentary deposition period. For the T8 sediment sample collected in the reservoir, located near the spillway, we identified that its sedimentary column was 32 years old and its sedimentation rate corresponds to 1.83 cm.year-1. Its geochronology amplitude corresponded to the years from 2014 to 1982. The results presented a good similarity, showing that these data present a conservative behavior, confirming that the application of the geochronological analysis through the plotter $210 \mathrm{~Pb}$ demonstrates its great utility as an environmental tracer for sediment studies. It is important to emphasize that the sediment granulometry is correlated with the geochronological analysis, since the concentrations of the geochronological plot correlated with the highest concentrations of the zinc and nickel metals, due to the fact that the determination of the metal content is associated with the fine fraction of the same $(<63 \mu \mathrm{m})$ silt and clay and, because they are located in the same layer and sediment sampled (T1, T6 and T8). 
Over the last few decades there has been an increase in research based on the use of these natural radionuclides in the environment, especially in research involving sediments, such as studies published by Aguirre (2001); Godoy et al. (2002); Fávaro et al. (2006); Silva et al. (2011); Damatto et al. (2013); Fernandes and Poleto (2017b).

\subsection{Volume of Sediments Silted in the Reservoir Mãe d'Água Dam}

In order to calculate the useful volume of the Mãe d'Água dam, a search on the design characteristics in 1962 was carried out, on the date of its construction using bibliographical references and on the technical bases from field sampling in 2014, 2015 and 2016.It was established two periods as a reference for the sizing of useful volumes and silting. The volume of sedimentation in reservoirs is an issue that must be addressed because such value will determine the success or useful life of an enterprise.

As a basis for the calculations, we followed the data published by Fujmoto (2002), such as the adoption of an average depth of 3.15 meters, crown length of 200 meters, and the existence of a layer of sealing. From the project made available for consultation in situ, by the library of the Hydraulic Research Institute of the Federal University of Rio Grande do Sul, we obtained the data published by the extinct National Department of Sanitation Works (DNOS), presenting values referring to the useful volume and quota of the spillway being $132.462,00 \mathrm{~m}^{3}$ and $104,40 \mathrm{~m}$, respectively.

Initially, an operation was carried out to identify, through the digital elevation model, which regions were silted for each dimension, based on the depths of the sampled samples, since those represent the layers of overlapping sediments. With the help of the software AutoCAD Civil 3D 2018, we performed the calculation of the volume of silted sediments.

Table 2 shows the data concerning the values of Quota vs. Area vs. Volume for the dimensioning of the volume of silted sediments in the interior of the Mãe d'Água dam dating from 1962 year of its inauguration to 2014 year of the samplings, establishing the volume silted in the last decades.

Table 2: Quota vs. Area vs. Volume; Method: Conic Approximation Method.

Conic Approximation Method (AutoCAD Civil 3D 2018) Volume of Sediments (Silting)

Quota (m) Layer height $(\mathrm{m})$ Area $\left(\mathrm{m}^{2}\right)$ Volume $\left(\mathrm{m}^{3}\right)$ Volume increased $\left(\mathrm{m}^{3}\right)$

\begin{tabular}{lllcc}
\hline 101.25 & 0.00 & $38,360.75$ & 0.00 & 0.00 \\
\hline 101.45 & 0.20 & $38,972.67$ & $7,733.26$ & $7,733.26$ \\
\hline 101.53 & 0.08 & $39,150.65$ & $3,124.93$ & $10,858.19$ \\
\hline 101.61 & 0.08 & $39,328.80$ & $3,139.18$ & $13,997.37$ \\
\hline 101.69 & 0.08 & $39,507.13$ & $3,153.43$ & $17,150.80$ \\
\hline 101.77 & 0.08 & $39,685.63$ & $3,167.71$ & $20,318.51$ \\
\hline 101.85 & 0.08 & $39,864.31$ & $3,181.99$ & $23,500.50$ \\
\hline 101.93 & 0.08 & $40,043.16$ & $3,196.30$ & $26,696.80$ \\
\hline 102.01 & 0.08 & $40,222.20$ & $3,210.61$ & $29,907.41$ \\
\hline 102.05 & 0.04 & $15,446.81$ & $1,074.60$ & $30,982.01$ \\
\hline 102.09 & 0.04 & $21,867.73$ & 742.58 & $31,724.59$ \\
\hline 102.17 & 0.08 & $21,995.91$ & $1,754.54$ & $33,479.13$ \\
\hline 102.25 & 0.08 & $22,123.00$ & $1,764.75$ & $35,243.88$ \\
\hline
\end{tabular}




\begin{tabular}{c}
\hline Conic Approximation Method (AutoCAD Civil 3D 2018) \\
\hline Volume of Sediments (Silting)
\end{tabular}

Quota (m) Layer height $(\mathrm{m})$ Area $\left(\mathrm{m}^{2}\right)$ Volume $\left(\mathrm{m}^{3}\right)$ Volume increased $\left(\mathrm{m}^{3}\right)$

\begin{tabular}{llccc}
\hline 102.27 & 0.02 & $14,282.66$ & 361.21 & $35,605.09$ \\
\hline 102.33 & 0.06 & $21,570.71$ & $1,068.12$ & $36,673.21$ \\
\hline 102.41 & 0.08 & $21,695.99$ & $1,730.67$ & $38,403.88$ \\
\hline 102.49 & 0.08 & $21,821.67$ & $1,740.70$ & $40,144.58$ \\
\hline 102.51 & 0.02 & $15,375.87$ & 370.10 & $40,514.68$ \\
\hline 102.57 & 0.06 & $20,556.22$ & $1,074.21$ & $41,588.89$ \\
\hline 102.65 & 0.08 & $20,556.50$ & $1,644.51$ & $43,233.40$ \\
\hline 102.73 & 0.08 & $20,680.66$ & $1,649.48$ & $44,882.88$ \\
\hline 102.79 & 0.06 & $16,392.43$ & $1,109.70$ & $45,992.58$ \\
\hline 102.81 & 0.02 & $18,530.44$ & 349.01 & $46,341.59$ \\
\hline 102.89 & 0.08 & $18,649.68$ & $1,487.20$ & $47,828.79$ \\
\hline 102.91 & 0.02 & $15,146.85$ & 337.36 & $48,166.15$ \\
\hline 102.97 & 0.06 & $17,999.33$ & 993.16 & $49,159.31$ \\
\hline 103.03 & 0.06 & $16,264.28$ & $1,027.47$ & $50,186.78$ \\
\hline 103.05 & 0.02 & $16,370.39$ & 326.35 & $50,513.13$ \\
\hline 103.11 & 0.06 & $16,477.15$ & 985.42 & $51,498.55$ \\
\hline 103.13 & 0.02 & $14,741.62$ & 312.03 & $51,810.58$ \\
\hline 103.21 & 0.08 & $14,804.65$ & $1,181.85$ & $52,992.43$ \\
\hline 103.29 & 0.08 & $14,867.84$ & $1,186.90$ & $54,179.33$ \\
\hline 103.37 & 0.08 & $14,930.78$ & $1,191.94$ & $55,371.27$ \\
\hline 103.45 & 0.08 & $14,993.86$ & $1,196.98$ & $56,568.25$ \\
\hline 103.51 & 0.06 & $15,056.85$ & 901.52 & $57,469.77$ \\
\hline & & & & \\
\hline
\end{tabular}

After obtaining the values described in Table 2, Figure 3 was represented and it shows the volumes estimated for the same dimensions at which the contour areas were calculated. We performed the correlations between Quota versus Area and Quota versus Volume, in order to verify the consistency between the two variables.

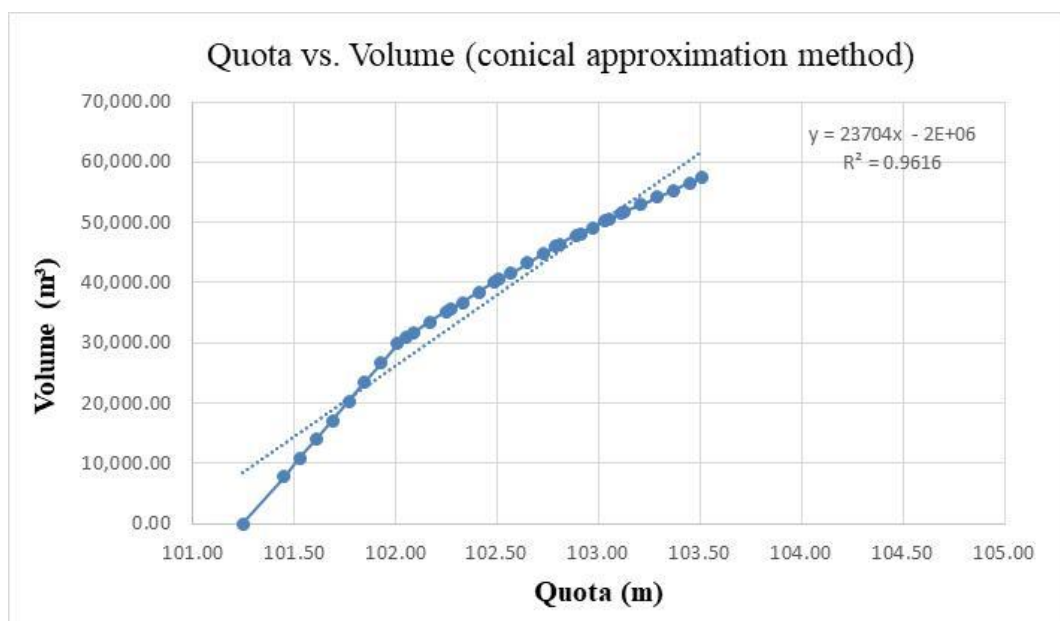

Figure 3: Quota vs. Volume relation of the sediments arranged in the Mãe d'Agua dam by conical approximation method. 
The results for the relations between the two variables showed a good correlation $(\mathrm{r}=$ 0.98), indicating that both presented good linearity with correlation between the data analyzed.

Based on the method of calculations presented in this research and through the results, we verified that between the years 1962 and 2014, the date of its construction in 1962 and the sampling of the sediment cores, the total volume of silted sediments within the Mãe d'Água dam was $57,469.77 \mathrm{~m}^{3}$. Such volume represents about $44 \%$ of the useful volume of the reservoir.

According to Araújo (2000), urban reservoirs undergo important environmental changes due to their location that facilitates anthropic interaction. When calculating the volume of sediments for the Apipucos reservoir, built in two cells and located in the urban area of Recife, it can be found a mean depth decrease of $15 \%$ and in cell 2 an average depth decrease of $11 \%$. Along with the author, these results prove quantitatively that cell 1 of the reservoir is more vulnerable to the ongoing silting process.

The Mãe d'Água dam presents sedimentary formation characteristics of the delta type, which is described by Coiado (2001) and Carvalho (2008), occurring inside the reservoir by sediments of various granulometries. It has as main consequence the gradual decrease of the useful volume of the dam. These two types of deposits (backwater and delta) can also interfere with navigation by reducing the depth of the watercourses.

Over the years, the river basin has been highly urbanized. The municipality of Viamão made feasible the construction of allotments and, as a result, there has been soil exposure and deforestation beyond the generation of environmental liabilities that would have the reservoir Mãe d'Água dam as final destination. Considering those anthropogenic actions, Figure 4 below characterizes the dam with the loss of its useful volume and with its silted bottom.

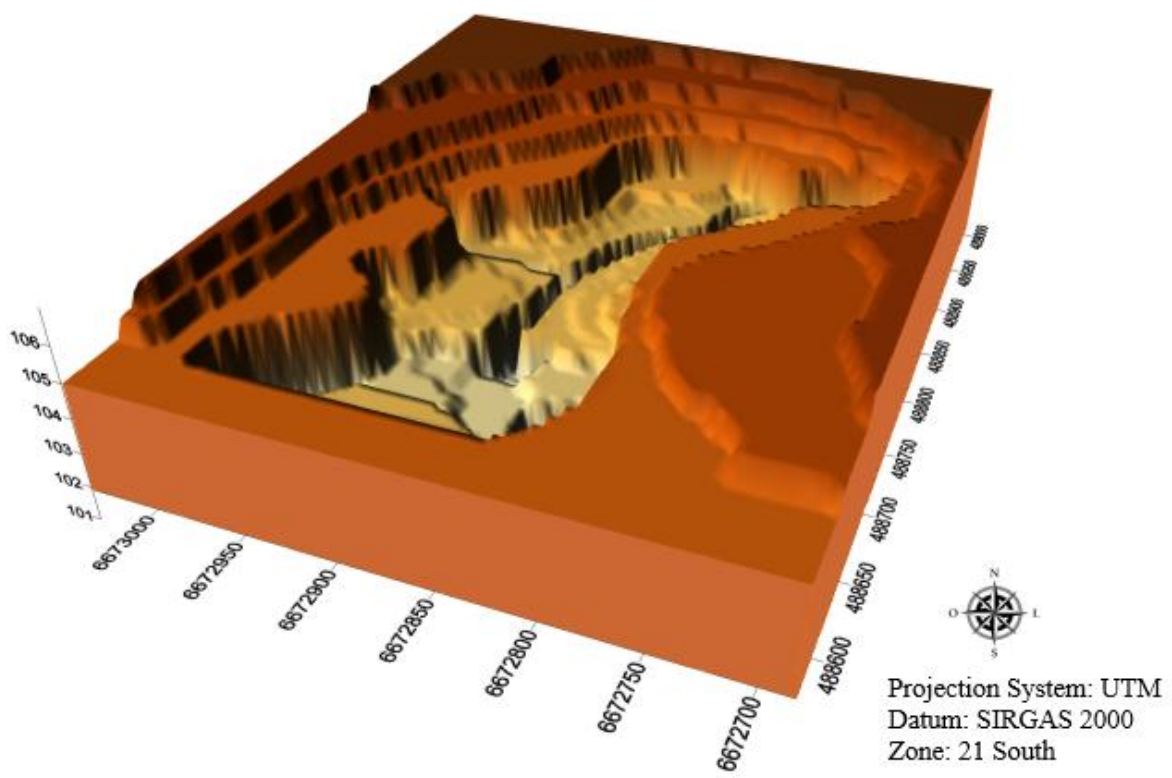

Figure 4: Digital terrain model (3D) representing the Mãe d'Água dam in 2014. 
We can verify that the largest deposits of sediment are concentrated in the edges of the dam in Delta form as described by Moris and Fan (2010). This result is consistent with the expected and with the 3D digital model shown in Figure 4. Larger deposits are formed in the reservoir backwater area, since in these regions material of various granulometries tend to sediment.

The useful volume in 2014 was determined by the difference between the water volumes in 1962 and the sediment volumes in 2014, calculated from the bathymetric data analyzes that corresponded to the influence of sediment volume deposited and compacted in each reservoir compartment. The values found were respectively $132,462.00 \mathrm{~m}^{3}$ for the useful project volume and $57,469.77 \mathrm{~m}^{3}$ for siltation, so we found that the volume in 2014 consisted of $74,992.23 \mathrm{~m}^{3}$, representing, approximately, $57 \%$ of the total useful volume. Therefore, since its creation until the present date of the collection, the Mãe d'Água dam presented a significant loss of its volume and storage capacity.

\section{Conclusion}

Observing and crossing the data of this study involving $210 \mathrm{~Pb}$ geochronology, sedimentation rate and geotechnology for the calculation of sediment accumulation inside the dam, it is noted that urbanization leads to high production of particulates carried by the water resources in the basin hydrologic and come from discovered soils, with no vegetation, causing sedimentation, as was verified in this study by the sedimentation rate and reduction of the useful volume over time in the Mãe d'Água dam. As a consequence, there is the increase in environmental liabilities due to diffuse sources of pollution present in the basin, such as heavy metals, organic matter, erosion, urban and industrial waste and construction, reduction of green or natural areas leading to degradation of the ecosystem.

Therefore, in order to increase the knowledge about the dynamics of urbanization and its impacts on sediments and, consequently, on the degradation of water bodies, there is a need to search for studies that carry out integrated studies on geochronology in sediments and geotechnologies, seeking to estimate sedimentation rates, geochronology of the sediments in the profile and the urbanization of the area over the decades, which will generate a correlation that allows to date the pollution / contamination data found in the water resources.

\section{References}

Almeida, K. Y. M. Uso do Po-210 na avaliação da taxa de sedimentação na Floresta Estadual "Navarro de Andrade", município de Rio Claro, São Paulo, SP. 2003. 73 f. Trabalho de Conclusão de Curso (Ecologia) - Instituto de Biociências, Universidade Estadual Paulista, Rio Claro, 2003.

Allen, J. R. L. et al. A comparison of the ${ }^{210} \mathrm{~Pb}$ date technique with three other independent dating methods in an oxide estuarine salt-marsh sequence. Estuaries, v. 16,n. 3B, p. 670-677, 1993.

Alexander, C. R. et al. The historical record of metal enrichment in two Florida estuarines, Estuarines, v. 16, n, 3B, p. 627-637, 1993.

Araújo, Alex Maurício. Evolução do processo de assoreamento em reservatório urbano. Anais... IV Encontro Nacional de Engenharia de Sedimentos e I Encontro de Engenharia de Sedimentos do Mercosul, Santa Maria-RS, 2000. 
Aguirre, E.S.M. Aplicación del método de fechado por ${ }^{210} \mathrm{~Pb}$ en sistemas acuáticos de Andalucía Occidental. 2001. Tese (Doutorado) - Universidad de Huelva, Espanha.

Bonotto, D. M.; Lima, J. L. N. ${ }^{210} \mathrm{~Pb}$-derived chronology in sediment cores evidencing the anthropogenic occupation history at Corumbataí River basin, Brazil. Environmental Geology, v. 50, p. 595-611, 2006.

Carvalho, N. O. 2008. Hidrossedimentologia prática. Rio de Janeiro: Interciência, $2^{\mathrm{a}}$ Ed. 599p.

Coiado, E.M. Assoreamento de reservatórios. In: Paiva J.B.D; Paiva E.M.C.D (Orgs.). Hidrologia aplicada à gestão de pequenas bacias hidrográficas. Porto Alegre: ABRH, 2001. p. 395-426.

Damatto S.R.; Santos L.F.; Barbiero L.; Furian S.M.; Rezende Filho A.T. Datação do sedimento lacustre recente do Pantanal da Nhecolândia - MS pelo método do ${ }^{210} \mathrm{~Pb}$ In: XIV Congresso Brasileiro De Geoquímica, 2013, Diamantina. Anais XIV congresso Brasileiro de Geoquimica, v. 1, p. 23-26, 2013.

EPA1996, U. S. Method 3050B: Acid Digestion of Sediments, Sludges, and Soils. Environmental Protection Agency: Washington, DC, USA, 1996.

USEPA - United State Environmental Protection Agency. (2009). USEPA 3050B, Method 3050B. Acid Digestion of Sediments, Sludges and Soils.

Fernandes, F., and Poleto, C. (2017a). "Concentrations and enrichment of metals in sediment cores: geochemistry and correlations with geoaccumulation index." Acta Scientiarum. Technology, 39(3) 349-356.

Fernandes, F.; Poleto, C; (2017b) Geocronologia e Amostragem Aplicada aos Sedimentos Límnicos, Utilizando o Radionuclídeo Chumbo (210Pb). In: Estudos Ambientais. POLETO, C. (Org.) - 1. Ed. Rio de Janeiro, Brasil. Interciência. p. 79-91.

Fujimoto, Nina Simone Vilaverde Moura. Alterações ambientais urbanas na área da bacia hidrográfica da barragem Mãe D'Água: evolução da ocupação e do uso da Terra. Boletim Gaúcho de Geografia, v. 28, n. $1,2002$.

Fávaro D.I.T.; Damatto S.R.; Silva P.S.C.; Riga A.A.; Sakamoto A.Y.; Mazzilli B.P. Chemical characterization and $210 \mathrm{~Pb}$ dating in wetland sediments from the Nhecolândia Pantanal Pond, Brazil. J. Radioanal. Nuclear Chem., v. 269 p. 719- 726, 2006.

Godoy, J.M.; Padovani, C.R; Guimarães, J.R.D.; Pereira, J.C.A.; Vieira, L.M.; Carvalho, Z.L.; Galdino, S. Evaluation of the Siltation of River Taquari, Pantanal, Brazil, through ${ }^{210} \mathrm{~Pb}$ Geochronology of Floodplain Lake Sediments. J. Braz. Chem. Soc., v. 13, n. 1, p. 71-77, 2002.

Lima, J. L. N. Hidroquímica pluvial e fluvial na Bacia do Rio Corumbataí (SP) e relações com o uso do Pb210 como geocronômetro. 2000. 260 f. Tese (Doutorado em Geociências) - Instituto de Geociências e Ciências Exatas, Universidade Estadual Paulista, Rio Claro, 2000.

Mcdonald, C. P.; Urban, N. R. Sediment radioisotope dating across a stratigraphicdiscontinuity in a miningimpacted lake. Journal of Environmental Radioactivity, v. 92,p. 80-95, 2007.

Mora, Tamires de Araujo (2015). Avaliação da concentração de atividade de Ra-226, Ra-228 e Pb-210 em sedimentos provenientes da Antártica na região da Baía do Almirantado. Tese de Doutorado. Universidade de São Paulo.

Morris, G.L.; FAN, J. Reservoir sedimentation handbook - design and management of dams, reservoirs, and watersheds for sustainable use. New York: McGraw-Hill Book, 2010. Electronic Version 1.04. 805 p.

Mozeto, A.A. Coleta de sedimentos de ambientes aquáticos continentais, extração de águas intersticiais e determinação granulométrica. In: MOZETO, A. A.; UMBUZEIRO, G. A.; JARDIM, W. F. Métodos de coleta, análises fisico-químicas e ensaios biológicos e ecotoxicológicos de sedimentos de água doce - Projeto Qualised. Cubo Multimidia, São Carlos, 2006. 26p.

Silva P.S.C.; Damatto S.R.; Maldonado C.; Fávaro D.I.T.; Mazzili B.P. Metal distribution in sediment cores from São Paulo State Coast, Brazil. Mar Pollut Bull, v. 62, p. 1130-1139, 2011.

Turner, L. J.; Delorme, L. D. Assessment of ${ }^{210} \mathrm{~Pb}$ data from Canadian lakes using the CIC and CRS models. Environmental Geology, v. 28, n. 2, p. 78-87, 1996. 